\title{
Performance of an Existing Reinforced Concrete Building Designed in Accordance to Older Indonesian Seismic Code: A Case Study for a Hotel in Kupang, Indonesia
}

\author{
Pudjisuryadi, P. ${ }^{*}$, Lumantarna, B. ${ }^{1}$, Setiawan, R. ${ }^{1}$, and Handoko, C. ${ }^{1}$
}

\begin{abstract}
The recent seismic code SNI 1726-2012 is significantly different compared to the older code SNI 1726-2002. The seismic hazard map was significantly changed and the level of maximum considered earthquake was significantly increased. Therefore, buildings designed according to outdated code may not resist the higher demand required by newer code. In this study, seismic performance of Hotel X in Kupang, Indonesia which was designed based on SNI1726-2002 is investigated. The structure was analyzed using Nonlinear Time History Analysis. The seismic load used was a spectrum consistent ground acceleration generated from El-Centro 18 May 1940 North-South component in accordance to SNI 1726-2012. The results show that Hotel X can resist maximum considered earthquake required by SNI 1726-2012. The maximum drift ratio is $0.81 \%$ which is lower than the limit set by FEMA 356-2000 (2\%). Plastic hinge damage level is also lower than the allowance in ACMC 2001.
\end{abstract}

Keywords: Indonesian seismic code; non-linear time history analysis; reinforced concrete; seismic performance.

\section{Introduction}

Earthquake is one of many loads that should be considered in designing a building. Seismic resistant buildings are designed against earthquake load based on seismic code which is periodically updated. The last update for Indonesian seismic code was from SNI1726-2002 to SNI 1726-2012 and the seismic hazard map is changed considerably. Besides the change of the seismic hazard map, SNI 17262012 also increases the maximum considered earthquake (MCE) level from 500 to 2500 year return period [1,2]. Peak bedrock acceleration map with 500 year return period in SNI1726-2002 is shown in Figure 1. While Figure 2 shows peak ground acceleration map with 2500 return period in SNI 1726-2012.

One example of this change is presented in Figure 3, for Kupang city in Indonesia (very dense soil). In Figure 3 the elastic design response spectra in SNI 1726-2012 which is $2 / 3$ of the response spectra of the $\mathrm{MCE}$ is compared to elastic design response spectra in SNI1726-2002.

${ }^{1}$ Civil Engineering Department, Faculty of Civil Engineering and Planning, Petra Christian University, Jl. Siwalankerto 121-131, Surabaya 60236, INDONESIA

* Corresponding author: pamuda@petra.ac.id

Note: Discussion is expected before June, $1^{\text {st }} 2018$, and will be published in the "Civil Engineering Dimension", volume 20, number 2, September 2018.

Received 12 February 2018; revised 12 March 2018; accepted 20 March 2018.

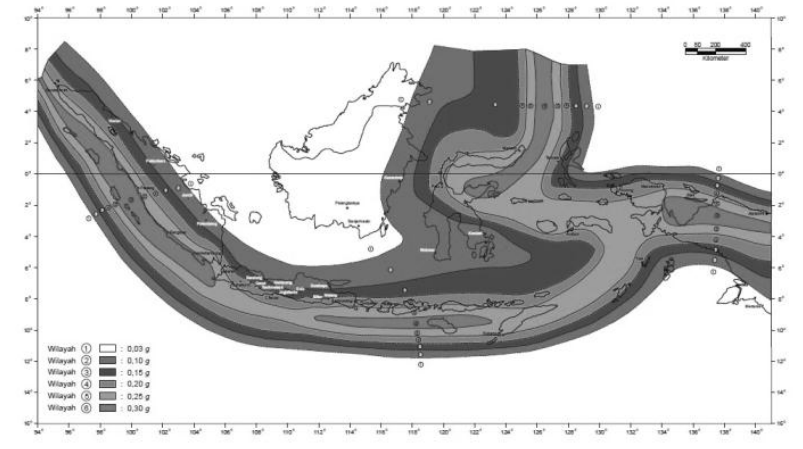

Figure 1. Peak Bedrock Acceleration Map with 500 Year Return Period in SNI1726-2002

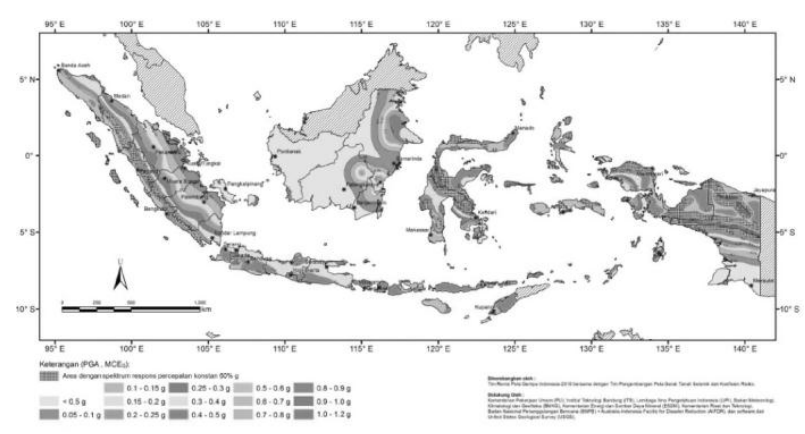

Figure 2. Peak Ground Acceleration Map with 2500 Year Return Period in SNI 1726-2012

The change of the elastic design response spectrum is not significant in this case. However SNI 17262012 introduces different seismic reduction factor. For dual systems structure (reinforced concrete special moment frames and shear walls), the seismic 
reduction factor in SNI1726-2002 is 8.5. While in SNI 1726-2012, the response modification coefficient is 7 . The resulting nominal earthquake loads (elastic design response spectrum divided by the seismic reduction factor) will differ more significantly. With lower nominal earthquake required in older seismic code, and higher maximum considered earthquake specified by the newer code, building performances designed with the older code are imperative to be investigated.

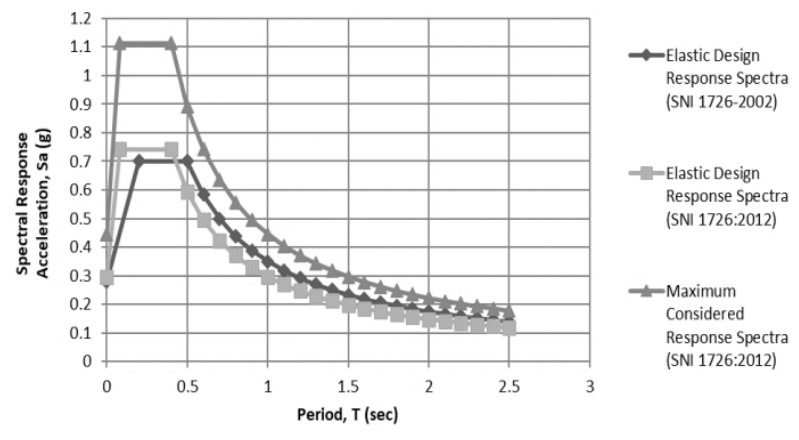

Figure 3. Comparison of Acceleration Response Spectra Between SNI1726-2002 and SNI 1726-2012 in Kupang City - Indonesia (very dense soil)

\section{Considered Building}

In this study, a six story Hotel $\mathrm{X}$ in Kupang, Indonesia with very dense soil site classification is chosen to be investigated. Besides the use of the older seismic code (SNI 1726-2002), the hotel was also designed based on older structural concrete code (SNI03-2847-2002). Indonesian structural concrete code was last updated from SNI03-2847-2002 to SNI 2847:2013 [3,4]. However, there were no significant changes in those structural concrete codes. The elevation and plan views of Hotel X are shown in Figure 4 and Figure 5, respectively. The shearwall positions are marked in Figure 5.

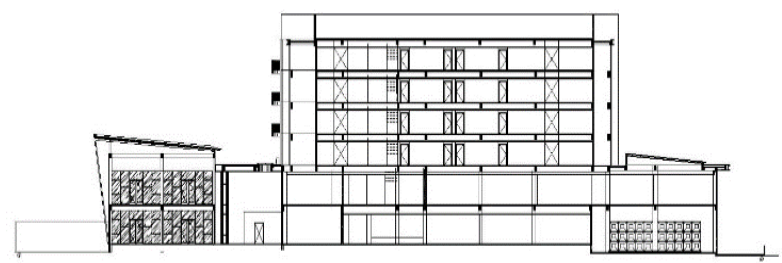

(a)

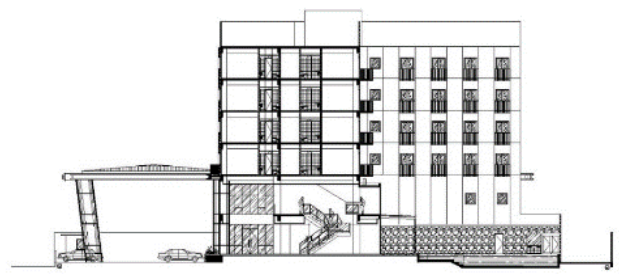

(b)

Figure 4. Elevation View of Hotel X: a) Longitudinal section; b) Transverse section

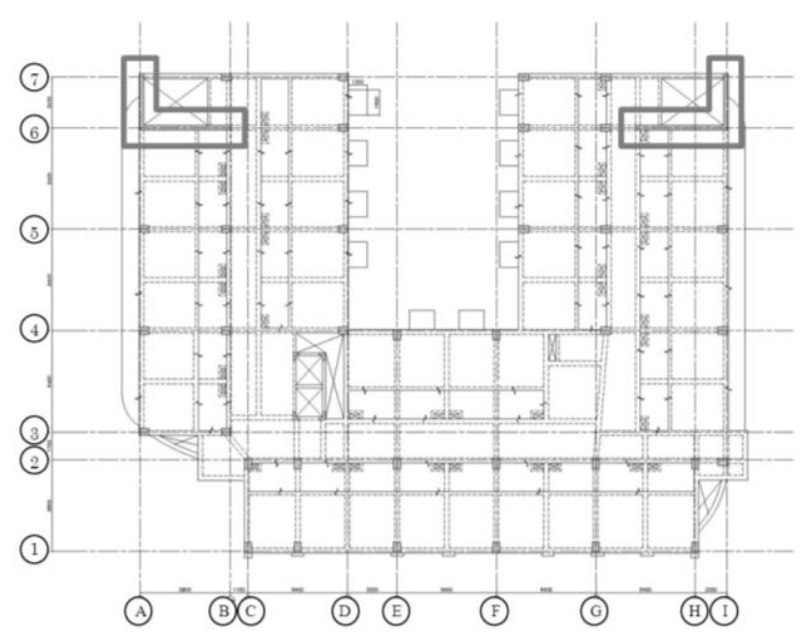

Figure 5. Typical Plan View of Hotel X (shown on the $3^{\text {rd }}$ floor)

\section{Analysis}

Hotel X structure was first modeled in SAP2000 software [5]. Because of some limitations on SAP2000, every L-shaped shear wall in the structure was modeled as two rectangular column elements which were connected using diaphragm joint constraint. The frame non-linear hinge properties (moment-curvature and force-displacement relationships) were generated using CUMBIA software [6]. The structure was then analyzed using Nonlinear Time History Direct Integration Analysis. The seismic load used was a spectrum consistent ground acceleration generated from El Centro 18 May 1940 North-South component in accordance to elastic design earthquake level (2/3 of MCE) and MCE of Kupang City based on SNI 1726-2012. The earthquake loads were applied on the structure twice as 1directional earthquake in $\mathrm{X}$ (longitudinal) and $\mathrm{Y}$ (transverse) directions.

\section{Building Seismic Performance}

Seismic performance of the structure was determined based on maximum drift ratio and plastic hinge damage level. Table 1 shows earthquake performance matrix and drift ratio limits for every performance level based on FEMA 356-2000 [7]. While damage index limits for every performance level based on ACMC 2001 is shown on Table 2 [8].

With the assumption that $2 / 3$ of MCE is comparable to earthquake with 500 year return period $(10 \%$ probability of exceedance in 50 years), according to FEMA 356-2000, the target performance levels for basic objective are " $k$ " and "p" in Table 1 (Life Safety Performance Level for elastic design earthquake, and Collapse Prevention Performance Level for MCE). While according to ACMC 2001, target performance levels for elastic design earthquake 
Table 1. Earthquake performance matrix based on FEMA 356-2000

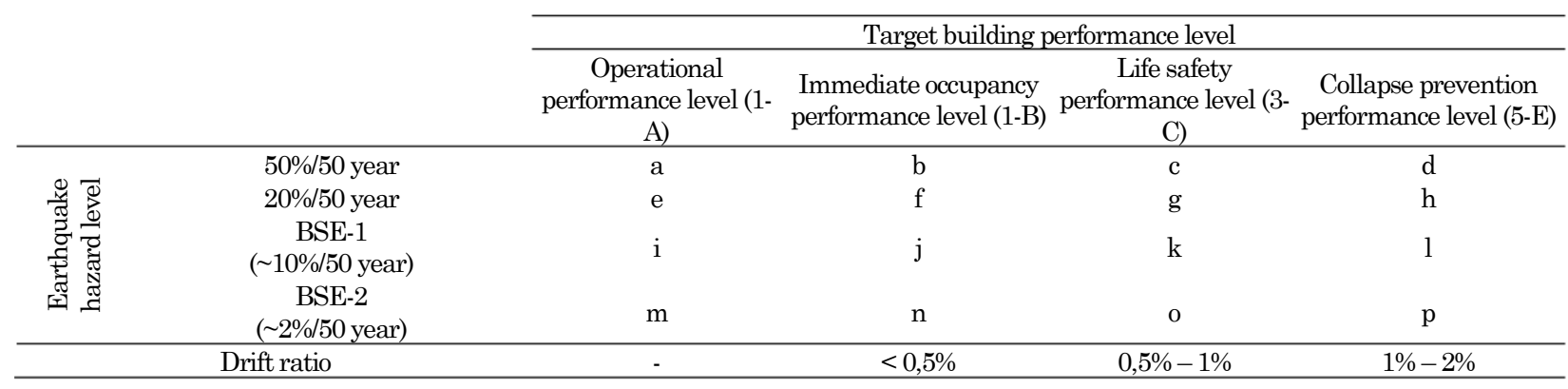

Table 2. Damage index limits based on ACMC 2001

\begin{tabular}{|c|c|c|c|c|c|}
\hline & & \multicolumn{4}{|c|}{ Seismic performance level } \\
\hline & & $\begin{array}{c}\text { Operational performance } \\
\text { level }\end{array}$ & Serviceability limit state & $\begin{array}{l}\text { Damage control limit } \\
\text { state }\end{array}$ & Safety \\
\hline \multirow{3}{*}{ 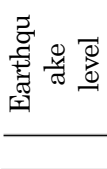 } & $\begin{array}{l}\text { Minor-to-moderate } \\
\text { earthquake }\end{array}$ & $\sqrt{ }$ & $\sqrt{ }$ & $\mathbf{X}$ & $\mathbf{X}$ \\
\hline & Severe earthquake & $\begin{array}{l}4 \\
y\end{array}$ & $\begin{array}{l}4 \\
y\end{array}$ & $\sqrt{ }$ & $\mathbf{X}$ \\
\hline & Damage index & $<0,1$ & $0,1-0,25$ & $0,25-0,4$ & $0,4-1$ \\
\hline
\end{tabular}

level and MCE (comparable to severe earthquake and ultimate earthquake) are Damage Control and Safety Limit State, respectively.

From the analysis results, story displacements, drift ratios, and member plastic hinge damage levels were recorded. Table 3 summarizes the story displacements and drift ratios of the structure in both directions due to elastic design and maximum considered earthquake levels. The same story displacements and drift ratios are also illustrated in Figure 6 and Figure 7, respectively. Moreover, the performance level limits according to FEMA 3562000 are also plotted in Figure 7. From Figure 7, it can be seen that the seismic performance of Hotel X according to FEMA 356-2000 is very good. Even when the Hotel X was subjected to MCE, the drift ratio still showed Life Safety Performance level in both directions.

Seismic performance of Hotel X was also determined based on the worst plastic hinge damage level due to the earthquake loads, with damage index limits set by ACMC 2001. Typical frame plastic hinge damages of the structure are shown in Figures 8 to 15. In those figures, centerline of the shear walls are marked with dotted line boxes, while the beams between the center line of the shear walls to the nearest plastic hinges are in fact rigid beams to simulate the width of the walls. Figures 8 to 11 show the frame damages due to design earthquake and MCE in x-direction, while Figures 12 to 15 show the frame plastic hinge damages in $\mathrm{y}$-direction. Plastic hinge damage marks used in the figures are listed in Table 4, which correspond to the performance levels set by ACMC 2001 (Table 2).

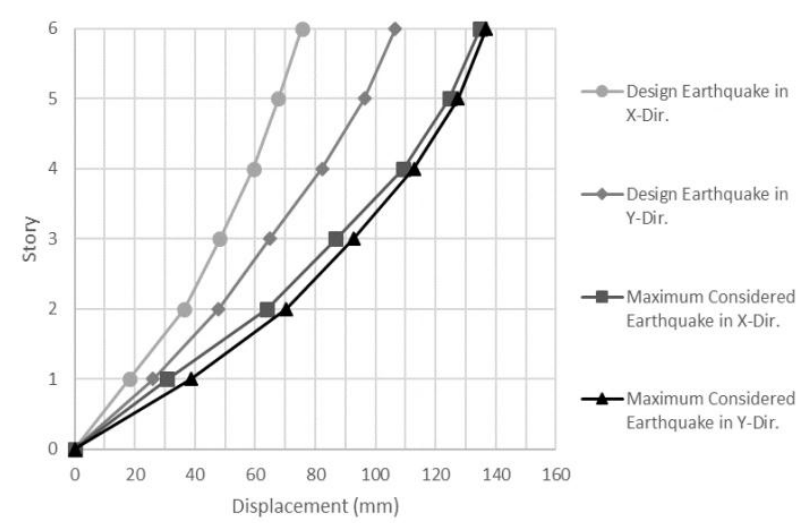

Figure 6. Hotel X Displacement Graph

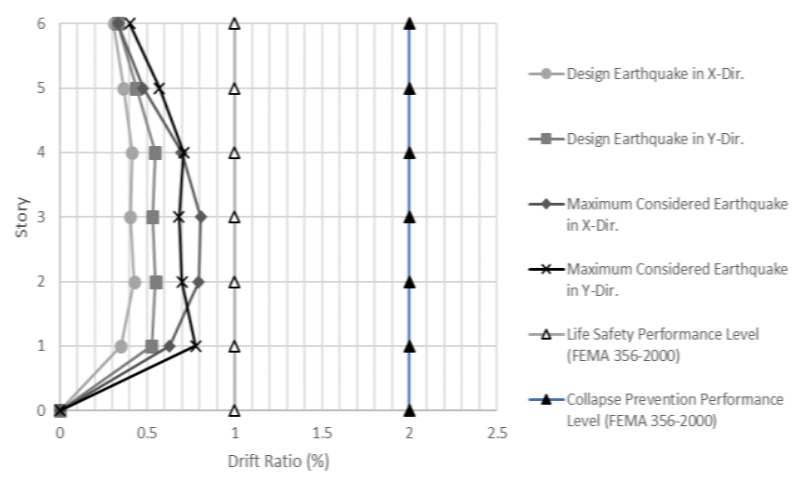

Figure 7. Drift Ratios of Hotel $\mathrm{X}$ due to Design and Maximum Considered Earthquake Compared to FEMA 356-2000 limits

Seismic performance of Hotel X was also determined based on the worst plastic hinge damage level due to the earthquake loads, with damage index limits set by ACMC 2001. Typical frame plastic hinge damages of the structure are shown in Figures 8 to 15 . In those figures, centerline of the shear walls are 
Table 3. Hotel $\mathrm{X}$ displacement and drift ratio

\begin{tabular}{|c|c|c|c|c|c|c|c|c|}
\hline \multirow{3}{*}{ Story } & \multicolumn{4}{|c|}{$\begin{array}{l}\text { Hotel X displacement } \\
(\mathrm{mm})\end{array}$} & \multicolumn{4}{|c|}{$\begin{array}{l}\text { Hotel X drift ratio } \\
(\%)\end{array}$} \\
\hline & \multicolumn{2}{|c|}{$\begin{array}{c}\text { Elastic design earthquake } \\
\text { level }\end{array}$} & \multicolumn{2}{|c|}{$\begin{array}{l}\text { Maximum considered } \\
\text { earthquake }\end{array}$} & \multicolumn{2}{|c|}{$\begin{array}{c}\text { Elastic design earthquake } \\
\text { level }\end{array}$} & \multicolumn{2}{|c|}{$\begin{array}{c}\text { Maximum considered } \\
\text { earthquake }\end{array}$} \\
\hline & X-dir. & Y-dir. & X-dir. & Y-dir. & X-dir. & Y-dir. & X-dir. & Y-dir. \\
\hline Roof & 75,53 & 106,59 & 134.76 & 136,84 & 0,3076 & 0,3338 & 0,3336 & 0,401 \\
\hline 5 & 67,61 & 96,28 & 124,47 & 127,41 & 0,3657 & 0,4386 & 0,4778 & 0,5706 \\
\hline 4 & 59,46 & 82,19 & 109,19 & 112,77 & 0,4148 & 0,5448 & 0,6977 & 0,7089 \\
\hline 3 & 48,26 & 64,72 & 86,86 & 92,66 & 0,405 & 0,5305 & 0,8079 & 0,6813 \\
\hline 2 & 36,52 & 47,82 & 63,91 & 70,41 & 0,4258 & 0,5483 & 0,7935 & 0,6992 \\
\hline 1 & 18,22 & 26,09 & 30,79 & 38,58 & 0,351 & 0,5265 & 0,6284 & 0,7786 \\
\hline
\end{tabular}

marked with dotted line boxes, while the beams between the center line of the shear walls to the nearest plastic hinges are in fact rigid beams to simulate the width of the walls. Figures 8 to 11 show the frame damages due to design earthquake and MCE in x-direction, while Figures 12 to 15 show the frame plastic hinge damages in y-direction. Plastic hinge damage marks used in the figures are listed in Table 4, which correspond to the performance levels set by ACMC 2001 (Table 2).

Table 4. Plastic hinge markers

\begin{tabular}{cc}
\hline Plastic hinge marker & Plastic hinge damage level \\
\hline & Operational performance level \\
Serviceability limit state \\
Damage control limit state \\
Safety limit state
\end{tabular}

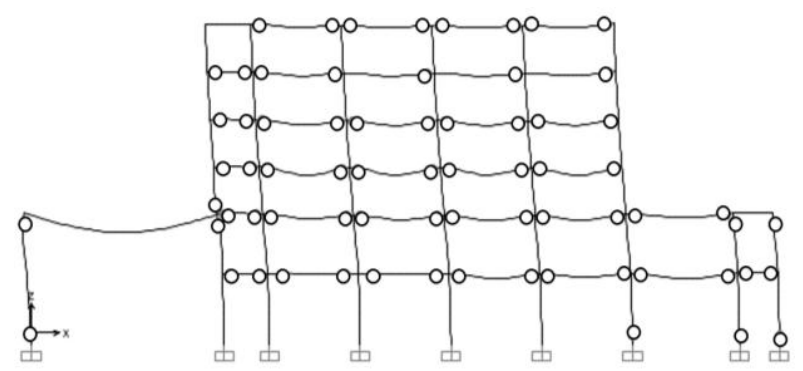

Figure 8. Frame 1 Plastic Hinges due to Design Earthquake in $\mathrm{x}$-direction
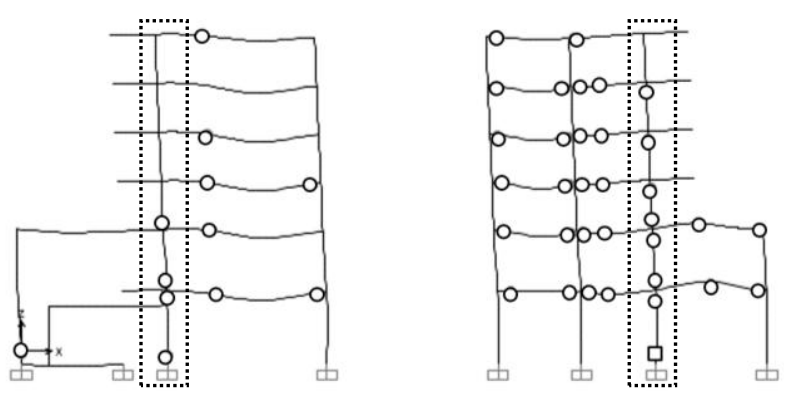

Figure 9. Frame 6 Plastic Hinges due to Design Earthquake in $\mathrm{x}$-direction

From Figures 8 and 9, it can be seen that the worst plastic hinge damage level due to design earthquake in $\mathrm{x}$-direction is serviceability limit state, which is on base of the right shear wall. The other plastic hinges on left shear wall, columns, and beams are on operational performance level. For elastic design earthquake, the worst plastic hinge damage level allowed in ACMC 2001 is damage control limit state. Therefore, Hotel $\mathrm{X}$ seismic performance due to design earthquake in $\mathrm{x}$-direction is very good.

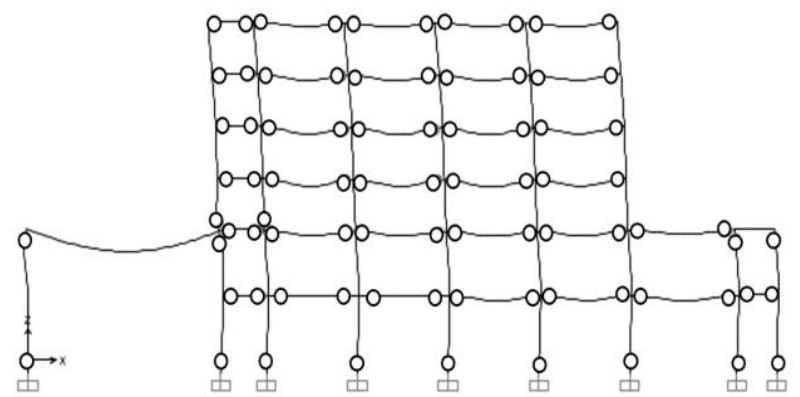

Figure 10. Frame 1 Plastic Hinges due to Maximum Considered Earthquake in x-direction
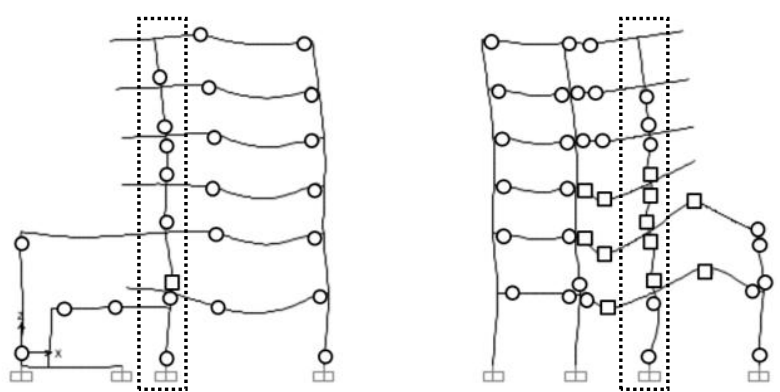

Figure 11. Frame 6 Plastic Hinges due to Maximum Considered Earthquake in $\mathrm{x}$-direction

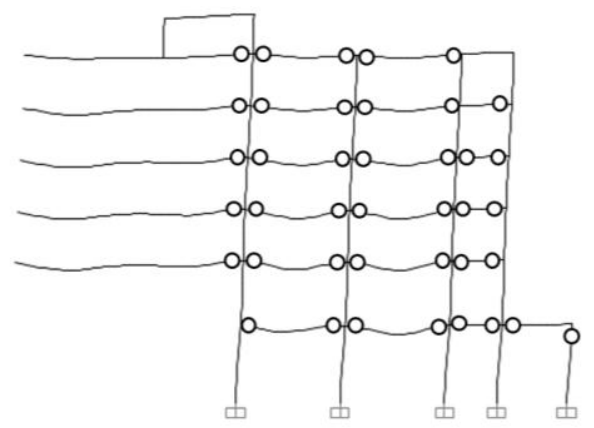

Figure 12. Frame D Plastic Hinges due to Design Earthquake in y-direction 


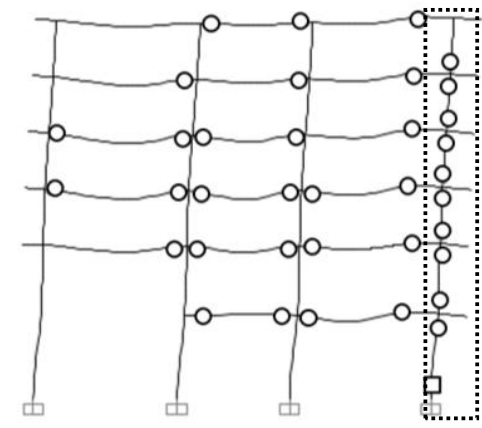

Figure 13. Frame I Plastic Hinges due to Design Earthquake in y-direction

Due to MCE in x-direction, the worst plastic hinge level is also serviceability limit state, which occurs on shear walls and a few beams. All plastic hinges on columns and majority of beams are on operational performance level. All plastic hinges on Hotel X due to MCE in x-direction is lower than the limit set by ACMC 2001, which is safety.

The worst plastic hinge damage level due to design earthquake in y-direction is on serviceability limit state, which occurs only on shear wall. All plastic hinges on columns and beams are on operational limit state. That means all plastic hinges on Hotel X due to design earthquake in $\mathrm{y}$-direction is lower than the limit set by ACMC 2001, which is damage control limit state.

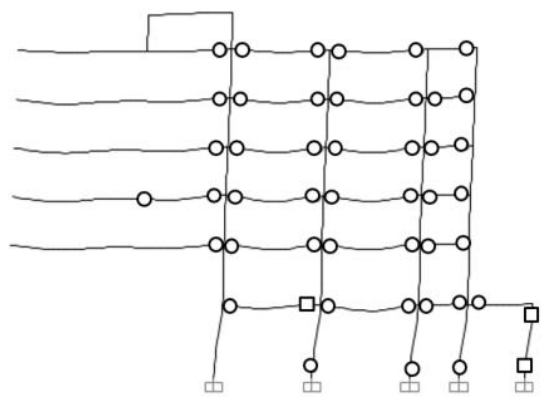

Figure 14. Frame D Plastic Hinges due to Maximum Considered Earthquake in y-direction

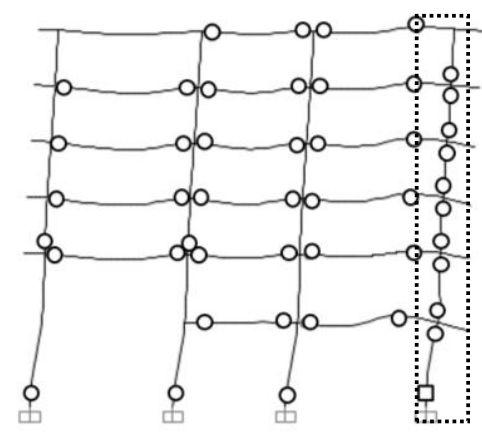

Figure 15. Frame I Plastic Hinges due to Maximum Considered Earthquake in y-direction

From Figures 14 and 15, it can be seen that majority of plastic hinges on Hotel $\mathrm{X}$ are on operational performance level. While a few plastic hinges on shear wall, columns, and beams are on serviceability limit state. As mentioned above, the worst seismic performance level allowed by ACMC 2001 due to MCE is safety. Therefore, Hotel $\mathrm{X}$ seismic performance level due to MCE in y-direction based on plastic hinge damage level is satisfactory.

From Figures 8 to 15, it can be concluded that Hotel $\mathrm{X}$ seismic performance based on plastic hinge damage level according to ACMC 2001 is satisfying. Table 5 summarizes Hotel $\mathrm{X}$ seismic performance based on plastic hinge damage level.

Table 5. Hotel X Seismic Performance according to ACMC 2001

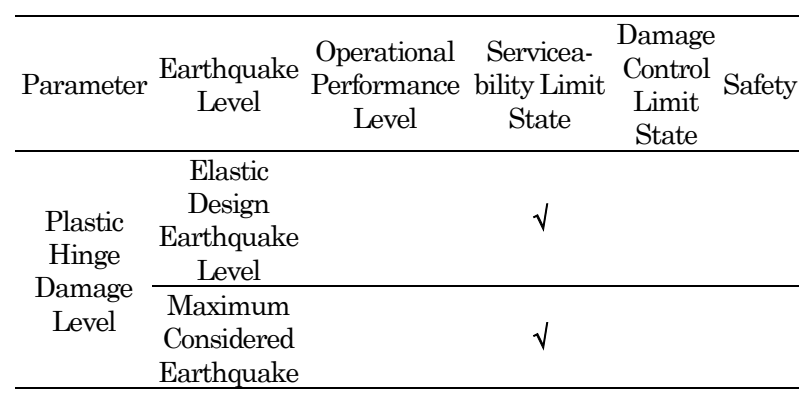

\section{Conclusion}

Indonesian seismic codes for designing earthquake resistant buildings are updated periodically, arising need to evaluate buildings designed by outdated codes. In this study, a reinforced concrete structure that was design based on older seismic code (SNI 17260-2002) was evaluated according the demand of newest code (SNI 1726-2012). From the analysis, it can be concluded that the seismic performance of the structure is still satisfactory compared to allowed limits. Hotel X maximum drift ratio due to elastic design earthquake level (0.55\%) and 2500 year return period earthquake $(0.81 \%)$ have not exceed the limits in FEMA 356-2000 (1\% and 2\%). Worst plastic hinge damage level (serviceability limit state due to both earthquakes) also has not exceeded the limits in ACMC2001 (damage control limit state for elastic design earthquake level and safety level for 2500 year return period earthquake).

\section{References}

1. SNI-1726-2002, Standar Perencanaan Ketahanan Gempa untuk Struktur Bangunan Gedung, Pusat Penelitian dan Pengembangan Teknologi Permukiman, 2002, (In Indonesian).

2. SNI 1726-2012, Tata Cara Perencanaan Ketahanan Gempa untuk Struktur Bangunan Gedung dan Non Gedung, Badan Standardisasi Nasional, 2012, (In Indonesian). 
3. SNI 2847:2013, Persyaratan Beton Struktural untuk Bangunan Gedung, Badan Standardisasi Nasional, 2013, (In Indonesian).

4. RSNI-03-2847-2002, Tata Cara Perhitungan Struktur Beton untuk Bangunan Gedung, Badan Standardisasi Nasional, 2002, (In Indonesian).

5. Computers \& Structures, Inc., CSI Analysis Reference Manual, Berkeley, California, USA, 2016.
6. Montejo, L.A. and Kowalsky, M.J., CUMBIASet of Codes for the Analysis of Reinforced Concrete Members, North Carolina State University, Raleigh, 2007.

7. FEMA 356-2000, Pre Standard and Commentary for the Seismic Rehabilitation of Buildings, American Society of Civil Engineers, 2000.

8. ACMC 2001, Asian Concrete Model Code Level 1 \& 2 Documents, International Committee on Concrete Model Code for Asia, 2001. 